\title{
THE REVEREND CHARLES SAMUEL POLLOCK PARISH - PLANT COLLECTOR \& BOTANICAL ILLUSTRATOR OF THE ORCHIDS FROM TENASSERIM PROVINCE, BURMA
}

\author{
Dudley Clayton
}

\author{
Royal Botanic Gardens, Kew, Richmond, Surrey TW9 3AB, United Kingdom \\ dudley.clayton@btinternet.com
}

\begin{abstract}
Charles Parish collected plants in Burma (now Myanmar) between 1852 and 1878. His orchid collections, both preserved and living plants, were extensive. He sent plant material and watercolour sketches to Sir William Hooker at Kew and living plants to the British orchid nursery of Messrs Hugh Low \& Co. of Upper Clapton. H.G. Reichenbach obtained examples of the Parish plant material from Hugh Low and he visited Kew where he studied the Parish orchid specimens and illustrations and many of them were subsequently described by Reichenbach. His beautiful and accurate watercolour paintings of orchids were bound in two volumes and eventually came to Kew following his death. They have been extensively used by botanists such as Robert Rolfe, Victor Summerhayes, Gunnar Seidenfaden and Jeffery Wood when working on the orchid floras of the region. Parish's life, collecting activities and collections are discussed here.
\end{abstract}

The name Parish as a collector of orchids in Burma (Myanmar) will be familiar to those who study orchids but it is unlikely that many people will know very much about him. Charles Samuel Pollock Parish (1822-1897) (Fig. 1), like many of his contemporary clergymen in the 19th century, pursued his calling and combined this with the benefits of his classical education. His abiding interest was in natural philosophy, which he pursued with considerable vigour and specifically, botany and geology. He was born, the second son of the Reverend Henry Parish (1791-1873), on the 26th January 1822 at Dum Dum, a town about 4 miles northeast of Calcutta (Kolkata) in India and the primary artillery cantonment for the Bengal Army of the Honourable East India Company (HEIC). Henry Parish was appointed Chaplain in the HEIC in 1820 and shortly after Charles was born, he became Senior Chaplain, with the Garrison of Fort William in Calcutta. This was followed by service at Agra from November 1826 and this is where he remained until he retired in 1839 after completing eighteen years' service (McNally, 1976). A few months after their arrival at Agra, Henry Thomas, the eldest of three sons died, aged seven years.
No record has yet been found, but it is most likely that Charles Parish returned to England for his formal education in 1832 or thereabouts, aged ten. On 12th December 1837, aged fifteen, he was admitted to St Edmund Hall, Oxford where he was awarded a Bachelor of Arts degree on 2nd December 1841. Shortly after leaving Oxford, he moved to Somerset and at the general ordination held by the Lord Bishop of Bath and Wells on 7th June 1846 (Bath Chronicle and Weekly Gazette, 1846), he was ordained into Holy Orders as a deacon and then as a priest on 30th May 1847 (Sherborne Mercury, 1847). On 15th August 1846 he was appointed curate at West Hatch, Somerset (Exeter and Plymouth Gazette, 1846) but he moved during December 1849 to his second curacy at Bickenhall and Orchard Portman (Sherborne Mercury, 1849).

Parish started collecting plants in 1844 in the neighbourhood of Esher, Surrey, where he resided with his parents who had, following their return from India, based themselves to be near Epsom, the Parish family home. Charles Parish widened his search for plants to other parts of Surrey, Sussex and the London area and by 1845 he extended his collecting to Kent, where the Parish family had connections. In 1845 he

* This paper was prepared in the framework of the celebration of Lankester Botanical Garden's $40^{\text {th }}$ anniversary. 


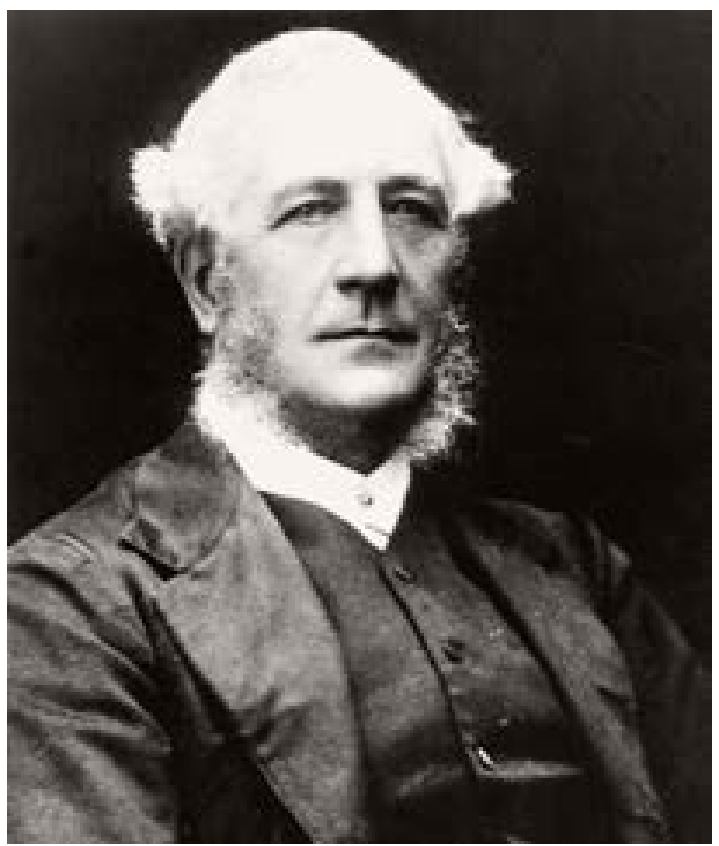

Figure 1. Reverend Charles Samuel Pollock Parish (1822-

1897). Reproduced with the kind permission of the Director and the Board of Trustees, Royal Botanic Gardens, Kew.

visited Ayrshire, the Isle of Arran and Loch Lomond in the west of Scotland. Specimens were collected in Somerset from 1845 and in 1846 he visited Ireland. During the period 1846-1849, he collected more than 100 specimens each year, mainly from Somerset, neighbouring Wiltshire and Devon. He also made an extensive collection in Wales; in Snowdonia, along the west coast and in the north. His specimens were named and preserved to form a herbarium that includes a range of temperate terrestrial orchids (now deposited with the Somerset Heritage Centre).

To complement his botanical interest, he developed an understanding of geology and the Blue Lias formations at Lyme Regis with their rich source of fossils. With his keen scientific intellect, he explored the geology of Somerset and assembled a large collection of fossils. Sadly, this no longer exists and it was possibly dispersed and absorbed into other collections. To gain a better understanding of geology, he purchased Lyell's Elements of Geology and Principles of Geology and, as a result, he was fascinated with the description of a volcanic island in the Bay of Bengal (Parish, 1861):
"I was particularly taken by the description of a certain volcanic island still active and standing up, far from land, like a solitary sentinel, in the Bay of Bengal, called 'Barren Island'. Besides its isolated position (for volcanoes are generally in groups) the remarkable feature of it, as described, was that the sea, entering by a gap in the outer crater, completely surrounded the inner or secondary crater, so that a boat could enter and be rowed round between the two.

I thought, as I read the account, how much I should like to see this strange island, not thinking at the time that there was the remotest likelihood of my ever doing so, situated as the place was on the other side of the world and, moreover, very much out of the ordinary trade vessels. But as it is 'the unexpected that always happens' so this extremely improbable thing, in course of time, actually came about."

In 1852, following in his father's footsteps, he obtained an appointment with the HEIC and he was placed under the authority of the Bengal Presidency, effective from 19th May 1852. He arrived in Calcutta to be immediately dispatched to Burma, embarking on another vessel bound for Rangoon (Yangoon) where he arrived in late May or early June 1852 at the height of the 2nd Anglo-Burmese War (1852). Rangoon had just been captured after a sea assault by the forces of the HEIC.

Charles Parish was to remain at Moulmein (Mawlamyaing) for the next 25 years, apart from a period of leave in England during 1872-73. He served initially as Assistant Chaplain, then as Chaplain from 1863 and finally, in 1873, after his return from leave, as a Senior Chaplain. His duties were to look after the European officers and men of the growing Company garrison and their dependents at Moulmein and the other smaller garrisons, with their dependents, in Tenasserim Province. Following the Indian Mutiny, the HEIC ceased to exist with the transfer of its responsibilities to the Crown from 1st November 1858, but life for the servants of the old Company did not change. As part of his duties, Parish was responsible for the governance of the European School in Moulmein and he also had to make periodic visits to the outlying stations at Tavoy (Dawei) and Mergui (Myeik), coastal stations to the south, some 200 miles $(320 \mathrm{~km})$ and 300 
miles $(480 \mathrm{~km})$ from Moulmein and he had to travel by boat. After 1858, a prison was opened at Port Blair on the Andaman Islands and Parish had to make regular visit to the islands as part of his duties.

In 1854, two years after he arrived in Moulmein, Charles Parish married Eleanor Isabella Sarah Johnson, the daughter of an officer of the 18th Regiment Native Infantry, Madras Army serving at Moulmein. They had seven children, four daughters and three sons, all born in Moulmein, but their second daughter only survived for one year. We know that Eleanor shared Charles' interest in botanical illustrating and a number of her illustrations form part of the collection in the two volumes donated to the Royal Botanic Gardens, Kew in 1898 by Eleanor, after the death of Charles Parish.

Parish now had the opportunity in Tenasserim to explore its forests and find a wide variety of plants, not just orchids. He was particularly impressed with the remarkable limestone rocks which stood perpendicularly out of a flat alluvial plain rising to $1000-2500 \mathrm{ft}(305-762 \mathrm{~m})$, generally straight and inaccessible. The pinnacles were worn by the rains into needle like points and they were wonderfully rich in plants, but only one in twenty could be climbed. His obvious desire to expand his botanical knowledge had to take second place to his duties and it meant he was unable to explore the region on a regular basis and make a systematic appraisal of the region. At best, he could venture some 20 miles ( $32 \mathrm{~km}$ ) from Moulmein. The administration of the province was in the hands of the district officers and they were required to tour their districts on a regular basis, including the exploration of the unknown areas, surveying, recording the geographic features, agricultural practices, crops, indigenous plants and wildlife. Parish's botanical knowledge made him a valuable companion to take on some of these expeditions. Even if he was unable to make a particular journey, the district officers would gather botanical material and Parish thus increased his overall knowledge. He initially collected mosses and ferns, and some flowering, non-orchid, species, but from 1859 , orchids became a major interest and it is mainly through the collecting and study of ferns and orchids that we know him.

The earliest preserved letter from Parish is in the Director's Correspondence at the Royal Botanic Gardens, Kew and is dated 31st July 1855. This letter and another from 31st August 1855 were written to Dr Thomas Thompson in response to enquiries made by Thompson when he was the Director at the Calcutta Botanic Gardens. Parish's letters were forwarded to Sir William Jackson Hooker (1785-1865), Director at the Royal Gardens Kew, because of the information they contained. Thompson identified Parish as a good contact for plant material from Tenasserim. Parish then began a regular correspondence with Sir William until just two months before the latter's death in August 1865. In addition to the letters, he sent regular consignments of plant material, mainly mosses, ferns and orchids, to Kew and orchids to Messrs Hugh Low \& Co. of Clapton. The first consignments sent in the summer of 1859 to Hugh Low included Cymbidium parishii Rchb.f. and Vanda gigantea Lindl. (= Vandopsis gigantea (Lindl.) Pfitzer), both discovered by Parish during the expedition he made in February 1859 with Major (later Colonel) Samuel Tickell (18111875). Vanda gigantea was growing high up on a tree and he never found it again, and the one plant he had brought down was so large it scarcely fitted on to his elephant. The specimen could be placed across a man's shoulders but one man could not lift it! The first consignment of plants sent to Messrs Low \& Co. was lost when the steamer Cape of Good Hope was cut in half by the P \& O steamer Nemesis, and sank in the Hooghly River. Various other trials and tribulations were suffered with plant material sent to England, with ships foundering and packages delayed en-route by the shipping companies. Eventually, he used with success the Wardian case, a small sealed glasshouse.

Colonel (later General) Robson Benson, who was based at Rangoon and collected for James Veitch \& Sons of Chelsea, was a friend of Parish. They met regularly and material was often exchanged. The annual visits to the outstations at Tavoy and Mergui were a highlight in Parish's year and as the European populations at these stations were small, Parish found he had sufficient spare time to explore the forests of Tavoy, Mergui and the Mergui Archipelago (Myeik Kyunzu). His comments on these visits were a regular feature of his letters to Sir William. Letters to Sir William's son, Joseph Dalton Hooker (1817-1911), who became Director at Kew after his father's death, were sporadic from 1862, but became regular again from 1865 until Parish retired in 1878. The memorable 


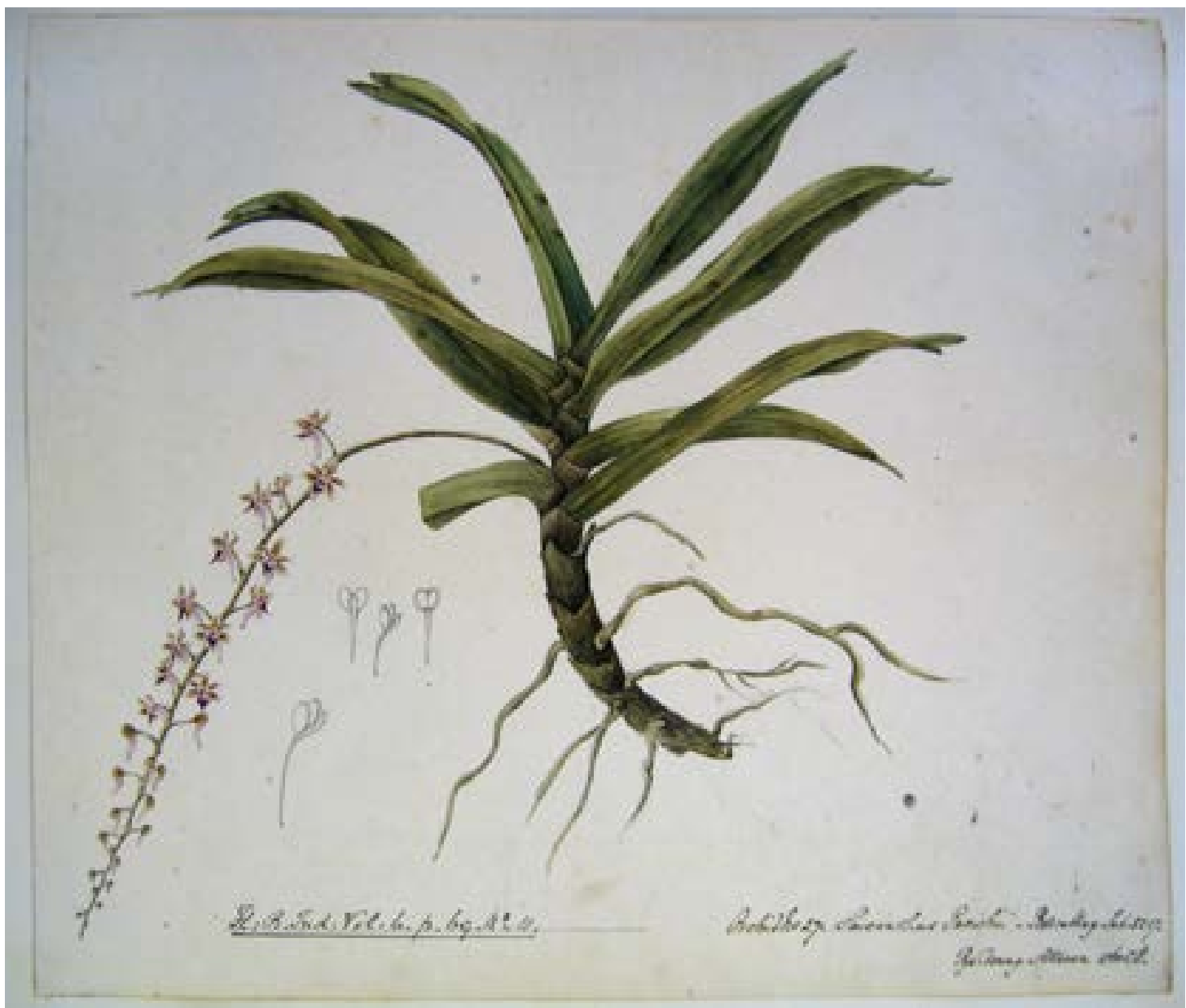

FiguRe 2. Cleisostoma parishii (Hook.f.) Garay in Bot. Mus. Leafl. 23: 173. 1972. Sarcanthus parishii Hook.f., Bot. Mag. 86: t. 5217. 1860. Type: Burma, cult. Low, Parish s.n. (holo. K). Parish illustration vol. 2, p. 56, dated 1860. Reproduced with the kind permission of the Director and the Board of Trustees, Royal Botanic Gardens, Kew.

record left by Parish concerning his visit to Barren Island, already alluded to, and now lodged with the British Library (Parish, 1861), occurred during one of the routine visits he made to the Andaman Islands. In mid-October 1861, the local steamer made a straight course from the mouth of the Tavoy River to Port Blair and Barren Island lay in almost a direct line between the two places. As the island came into view and as Parish and a few others were anxious to land, the master of the steamer agreed. Initially, the steamer was sailed around the island and then 'hove to' at a convenient distance from the shore. Parish records his disappointment at finding no intervening and surrounding water, as described by Lyell. He may not have known that there had been an eruption in 1852 and this coupled with earlier eruptions in the century, changed the character of the island. Two or three officers and Parish were rowed ashore and they explored the island. The only orchid referred to in the article was encountered on their descent from the summit of the volcano, when Parish caught sight of a pure white speck in strong contrast with the background of black ashes, near the bottom of the opposite slope, and he wanted to see what it was. It turned out to be a fine healthy plant of Dendrobium formosum, a common but extremely beautiful orchid and known to the Burmese as the 'Silver Flower'. It was in full bloom and Parish thought it must have fallen off some overhanging tree on the ridge and slid or been washed down by the rain to its singular position. 


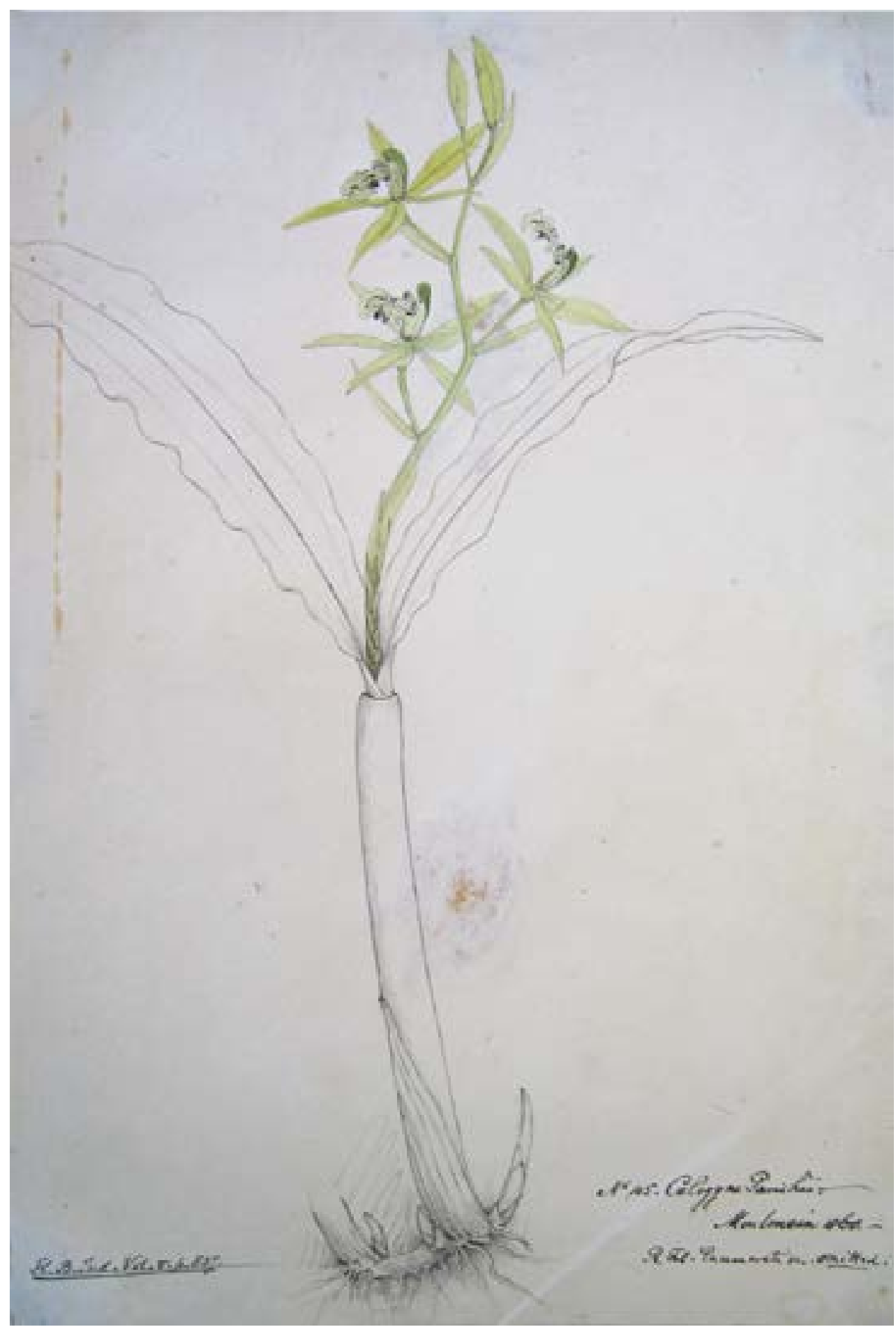

Figure 3. Coelogyne parishii Hook.f. in Bot. Mag. 88: t. 5323. 1862. Type: Burma, Tenasserim, Moulmein, cult. Low, Parish s.n. (holo. K). Parish Illustration vol. 1, p. 84, dated 1860. Reproduced with the kind permission of the Director and the Board of Trustees, Royal Botanic Gardens, Kew. 


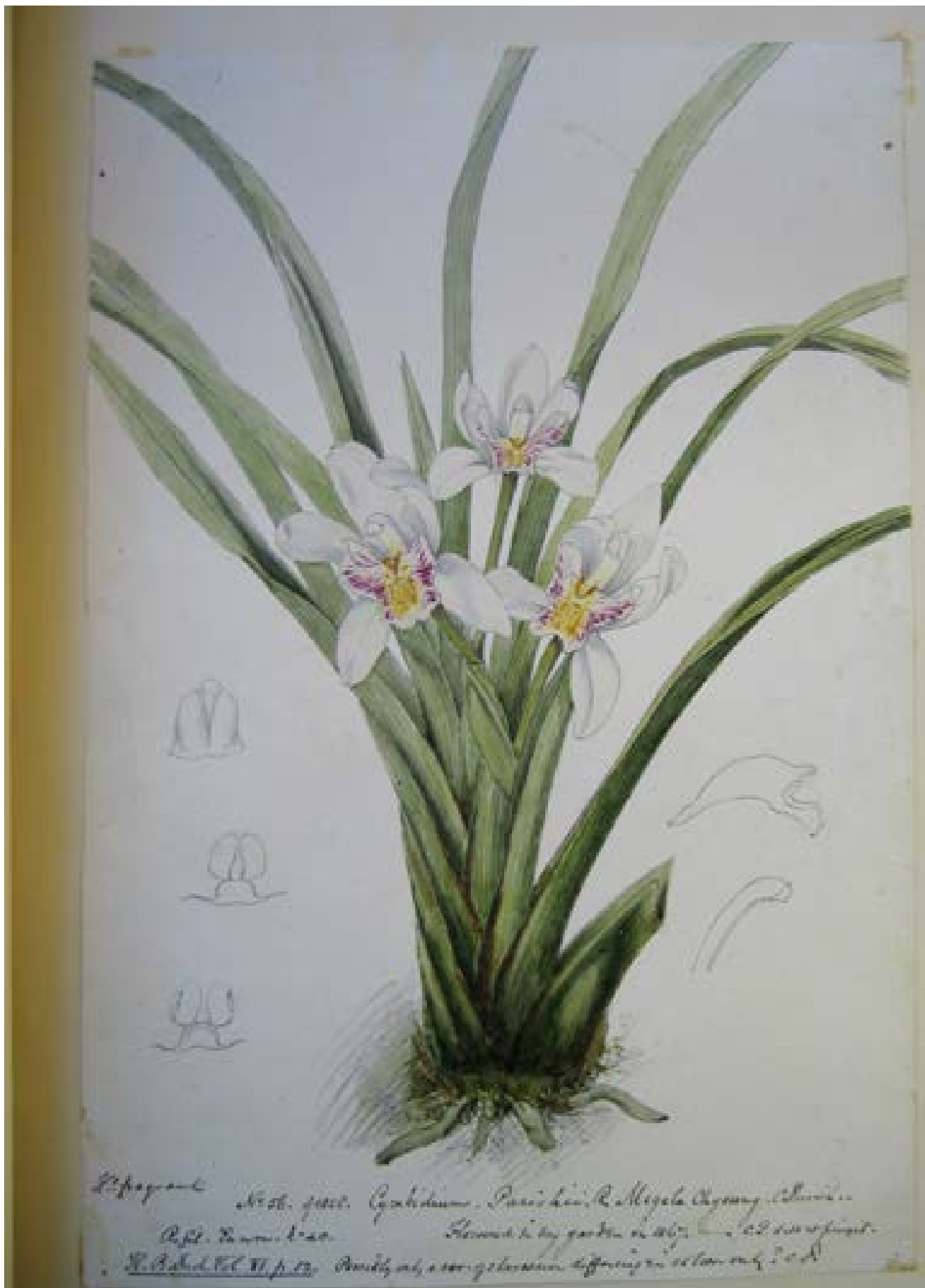

Figure 4. Cymbidium parishii Rchb.f. in Trans. Linn. Soc. London 30: 144. 1874. Type: Burma, Parish s.n. (holo. W). Parish illustration vol. 2, p. 19, dated 1867. Reproduced with the kind permission of the Director and the Board of Trustees, Royal Botanic Gardens, Kew. 
From 1859 Parish was writing articles and his discoveries were being discussed, in botanical journals. He identified some 350 indigenous orchids, and grew about 150 species in his garden. Parish used local knowledge as a means of obtaining material around Moulmein. A regular supply of plants arrived which he would plant in his garden and watch them grow, and as he remarked 'hardly a day passed on which I did not either draw or examine microscopically one orchid or another'. Finding suitable individuals to collect for him was not easy. In 1864 he lamented the loss of his regular Burmese collector who set a fire to drive a wild pig out of its lair, but died when the flames engulfed the tree that he had climbed to get out of the way.

Parish's 300 illustrations are bound in two volumes, each comprising about 80 pages. The pages are often annotated with more than one name and Dendrobium is the most abundant species in the record. Many are drawings of type material, including Cleisostoma parishii (Fig. 2), Coelogyne parishii (Fig. 3), Cymbidium parishii (Fig. 4), Dendrobium parishii (Fig. 5), Hygrochilus parishii (Fig. 6), Paphiopedilum parishii (Fig. 7), Peristylus parishii (Fig. 8), Porpax parishii (Fig. 9) and Phalaenopsis parishii (Fig. 10), were named in his honour by Reichenbach and Joseph Hooker. Reichenbach (1874) listed most of the more than 200 orchid species collected by Parish around Moulmein and described many novelties based on Parish's collections. Other Parish species were described by him in a variety of German and British journals.

Following his retirement, Parish made a substantial contribution on Orchidaceae in the third edition (1883) of Francis Mason's Burma, its people and productions; Notes on the fauna, flora and minerals of Tenasserim, Pegu and Burma. Vol. II, Botany, rewritten and enlarged by W. Theobald, who had just retired from his post as Deputy-Superintendent Geological Survey of India. A typical Parish entry concerns Vanda:

"I come now to a very puzzling group of orchids. I have lying on the table before me as I write, figures and illustrations of Vanda roxburghii, of $V$. roxburghii var. unicolor, $V$. bensonii, $V$. denisoniana, and of a Vanda of my own finding, which I have marked doubtfully, as $V$. bensonii. Size and colour apart, I look in vain for anything among all these which, in any other order of plants, would be reckoned sufficient for a specific distinction. ...."

Parish retired after more than 25 years in Burma, on 20th June 1878 but he remained an active clergyman in the Taunton area. His wife Eleanor and their children had remained at Taunton when Parish returned to Moulmein after his period of leave in 1872-73. On the 8 th July 1885 , it was reported that at the Orchid Congress held in London he was awarded a gold medal from the Royal Horticultural Society, in recognition of his exertions in connection with the importation of Burmese orchids, of which he was an extensive and enthusiastic collector when resident in the colony (Taunton Courier, and Western Advertiser, 1885). He died quietly in his sleep, on the 18th October 1897, aged 75, at Roughmoor House, his home in Bishop's Hull on the outskirts of Taunton.

ACKNOWLEDGMENTS. I am grateful to the Director of the Royal Botanic Gardens, Kew for enabling me to use the facilities at Kew as an honorary research associate. I particular wish to thank the staff of the Herbarium, Library and Archives for their valuable assistance with accessing Parish's illustrations and the Kew Director's Correspondence in relation to my on-going research of Charles Parish and his contribution to Orchidaceae. I also thank Dr Leonie Ryder of Brisbane, Queensland for providing me with her transcription of A Little Known Volcano. I also appreciated the opportunity to exchange information with her on the genealogical aspects of the Parish family, to which she has a maternal link back to a brother of Henry Parish. All images reproduced by kind permission of the Director and Trustees of the Royal Botanic Gardens, Kew.

\section{LiteRATURE CitED}

British Newspaper Archive, British Library, London; accessed via a personal subscription:

Bath Chronicle and Weekly Gazette 1749-1950; 11th June 1846.

Exeter and Plymouth Gazette 1827-1950; 15th August 1846. Sherborne Mercury 1789-1867; 12th June 1847 and 29th December 1849.

Taunton Courier, and Western Advertiser 1833-1963; 8th July 1885.

Kew Director's Correspondence (KDCAS651-657; KDCAS1812; KDCAS2090-2112; KDCAS2114-2138; KDCAS2155;KDCAS2809-2812; KDCAS2814-2826). Letters from CSP (Charles Samuel Pollock) Parish to 


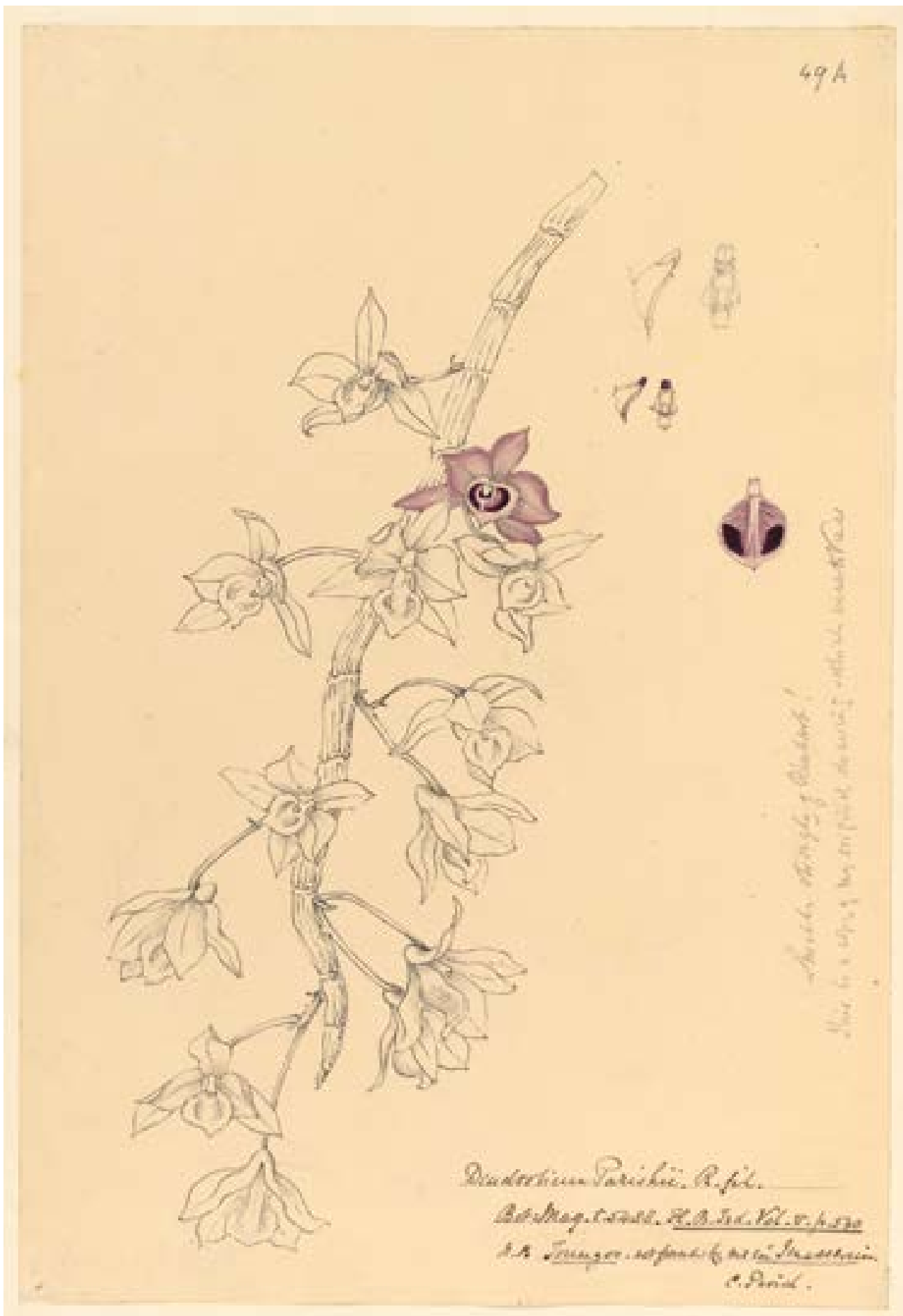

Figure 5. Dendrobium parishii Rchb.f. in Bot. Zeitung (Berlin) 21: 237 .1863. Type: Burma, Parish s.n. (holo. W). Parish illustration vol. 1, p. 49, dated 11 March 1882. Reproduced with the kind permission of the Director and the Board of Trustees, Royal Botanic Gardens, Kew. 


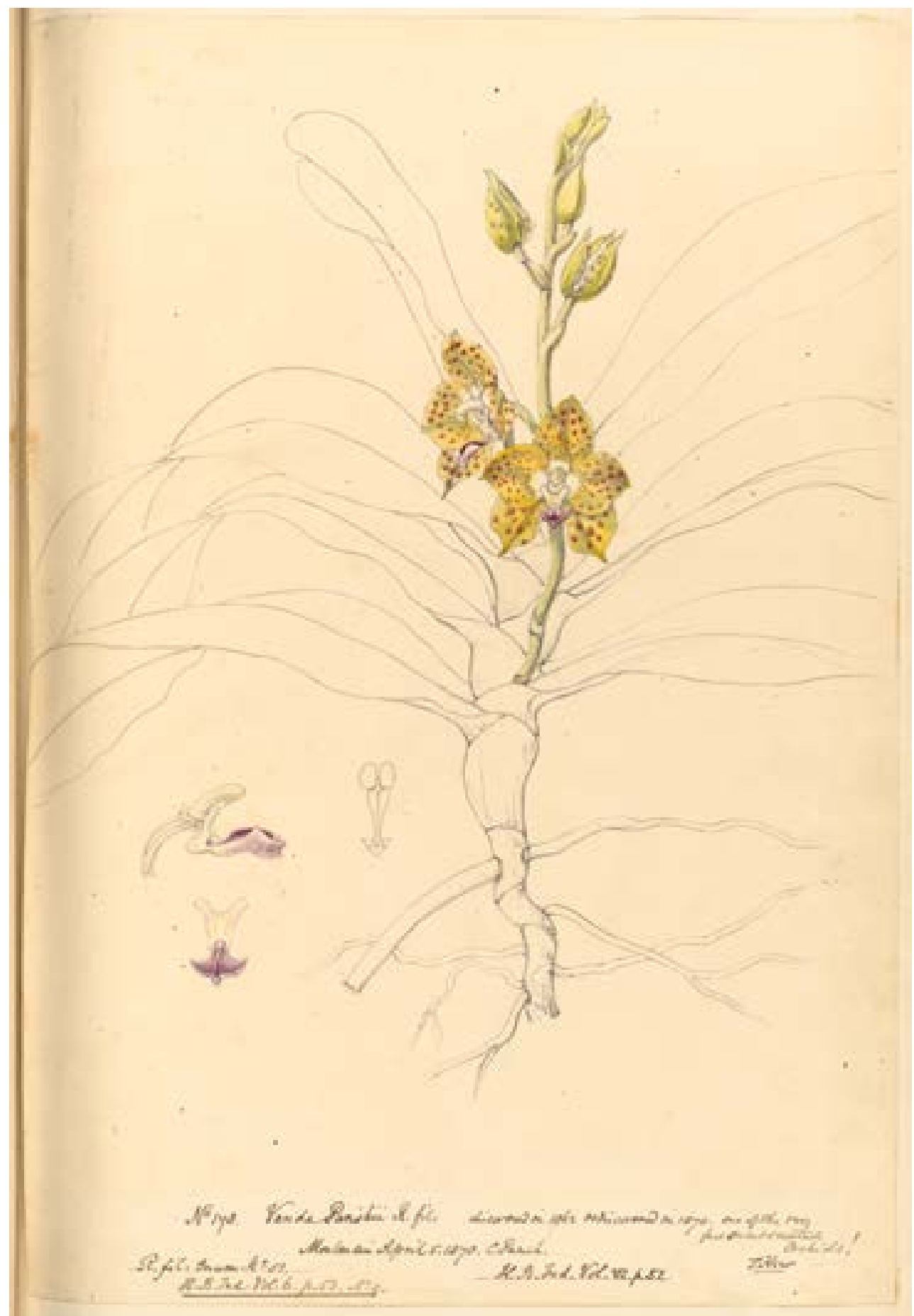

FIgURE 6. Hygrochilus parishii (Veitch \& Rchb.f.) Pfitzer in Engler \& Prantl (eds.), Nat. Pflanzenfam., Nachtr. 1: 112. 1897) Vanda parishii Rchb.f., Xenia Orchid. 2: 138. 1868. Type: Burma, Moulmein, Parish s.n. (holo. W). Parish illustration vol. 2, p. 29, dated 5 April 1870. Reproduced with the kind permission of the Director and the Board of Trustees, Royal Botanic Gardens, Kew. 


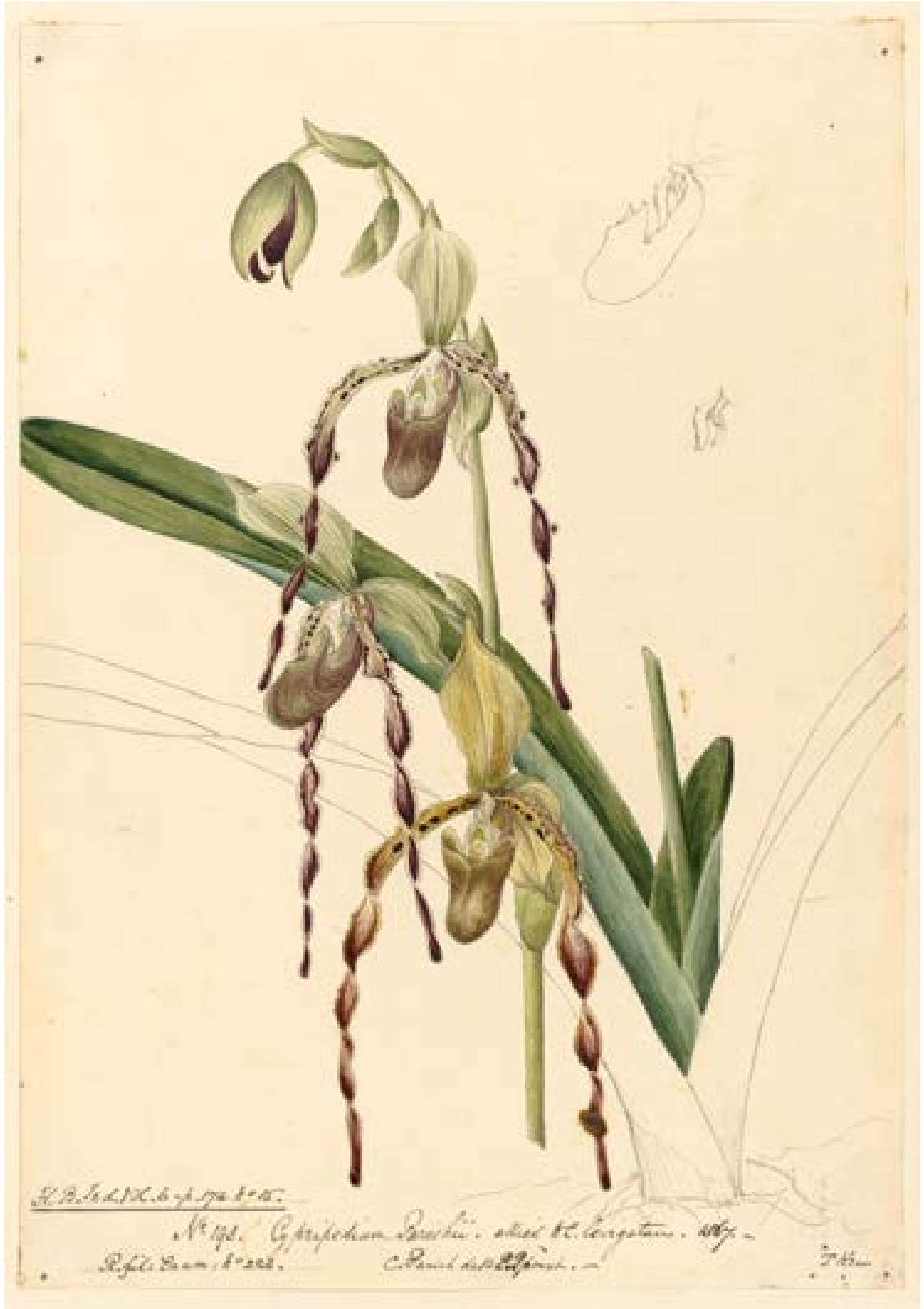

FIgURE 7. Paphiopedilum parishii (Rchb.f.) Stein, Orchideen-Buch: 479. 1892. Cypripedium parishii Rchb.f., Flora 52: 322. 1869. Type: Burma, Parish s.n. (holo. W-RCHB; iso. K). Parish illustration vol. 2, p. 88, dated 1867. Charles and Eleanor Parish are both identified as the artists. Reproduced with the kind permission of the Director and the Board of Trustees, Royal Botanic Gardens, Kew. 


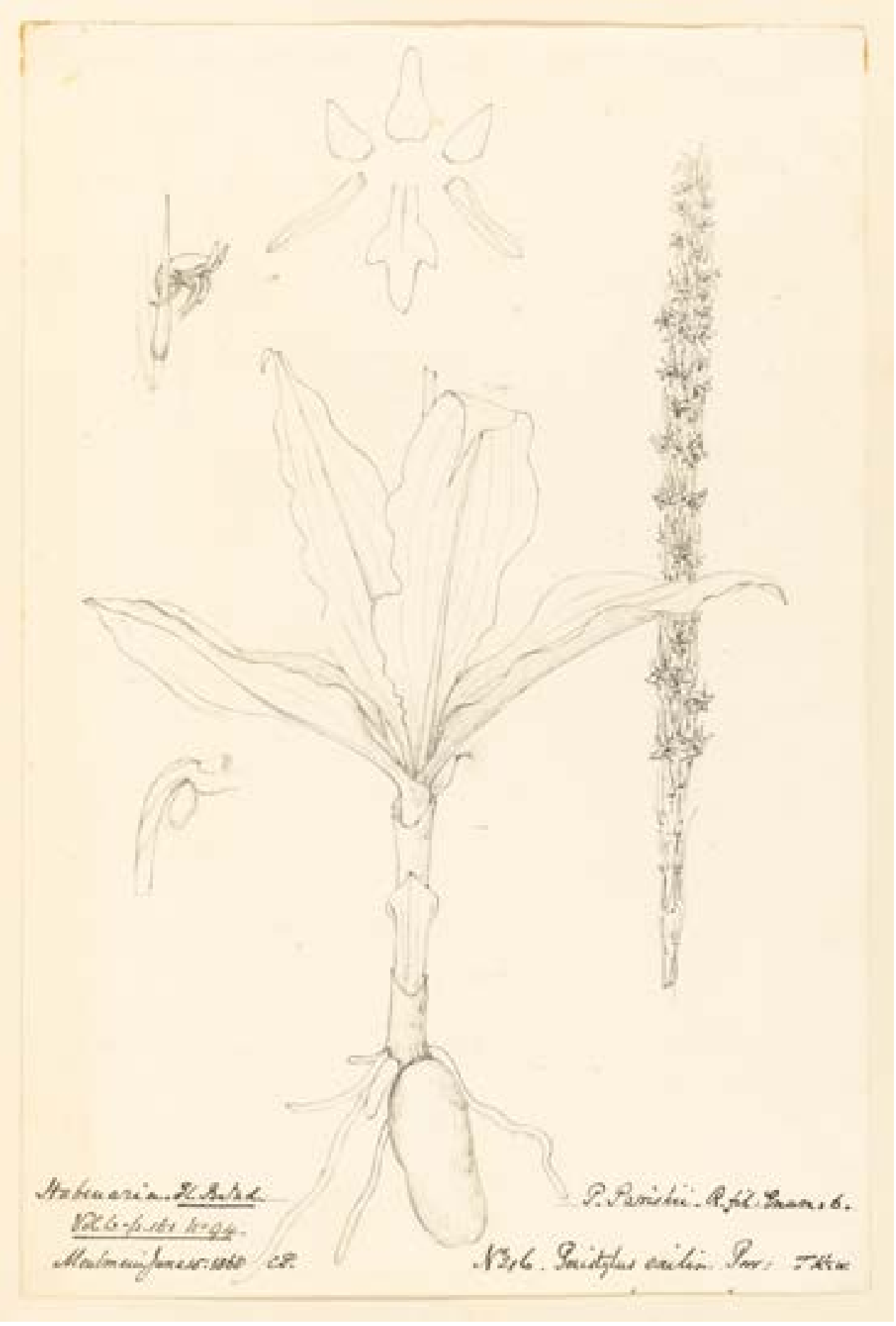

FIgure 8. Peristylus parishii Rchb.f. in Trans. Linn. Soc. London 30: 139. 1874. Type: Burma, Tenasserim, Moulmein, cult. Dawson, Parish s.n. (holo. W-RCHB; iso. K). Parish illustration vol. 2, p. 81, dated 15 June 1868. Reproduced with the kind permission of the Director and the Board of Trustees, Royal Botanic Gardens, Kew. 


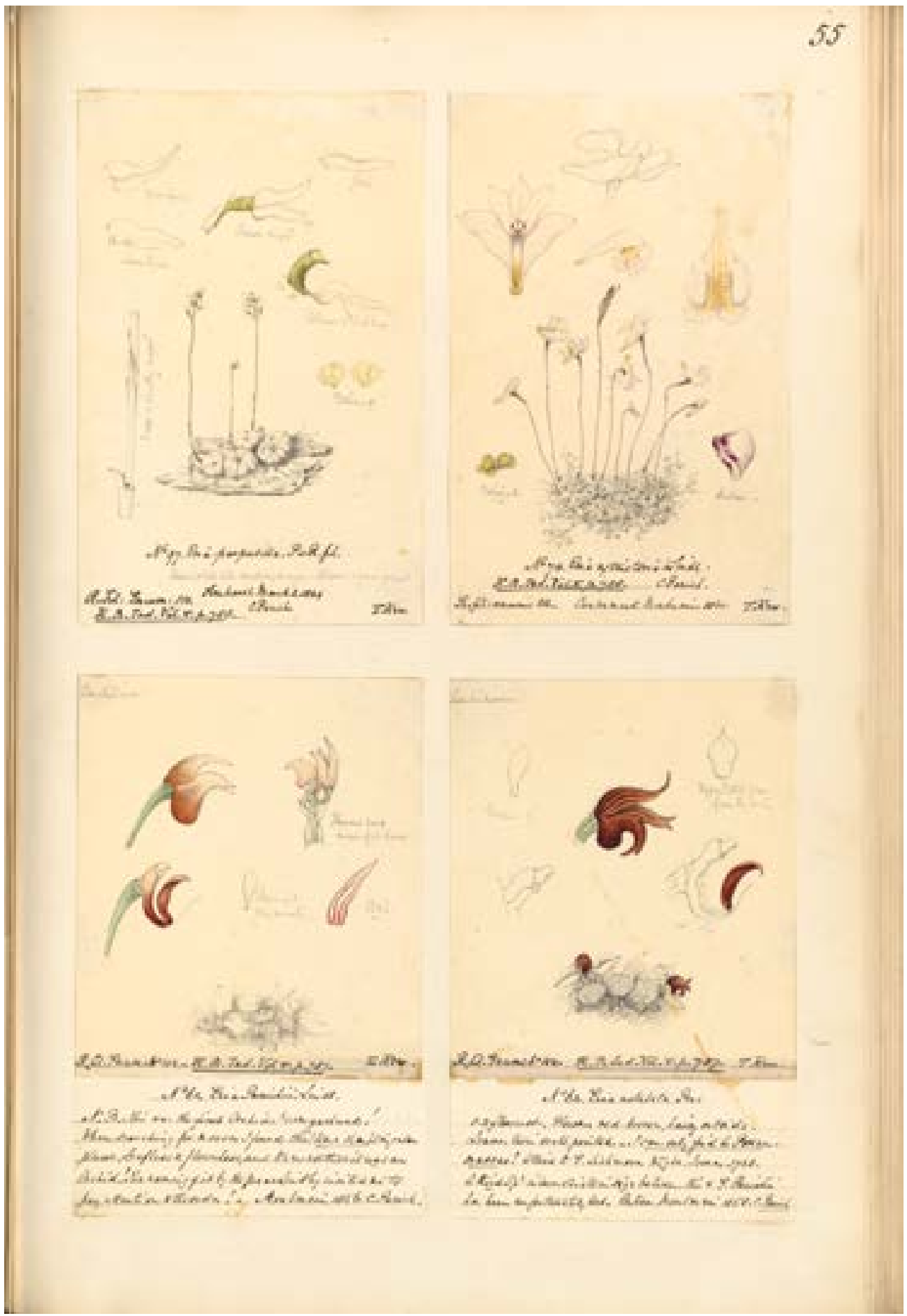

Figure 9. Porpax parishii (Lindl. \& Rchb.f.) Rolfe in Orchid Rev. 16: 8. 1908. Eria parishii Lindl. \& Rchb.f., Trans. Linn. Soc. London 30: 147. 1874. Type: Burma, Parish s.n. (holo. W). Parish illustration vol. 1, p. 55, dated 1856. Reproduced with the kind permission of the Director and the Board of Trustees, Royal Botanic Gardens, Kew. 


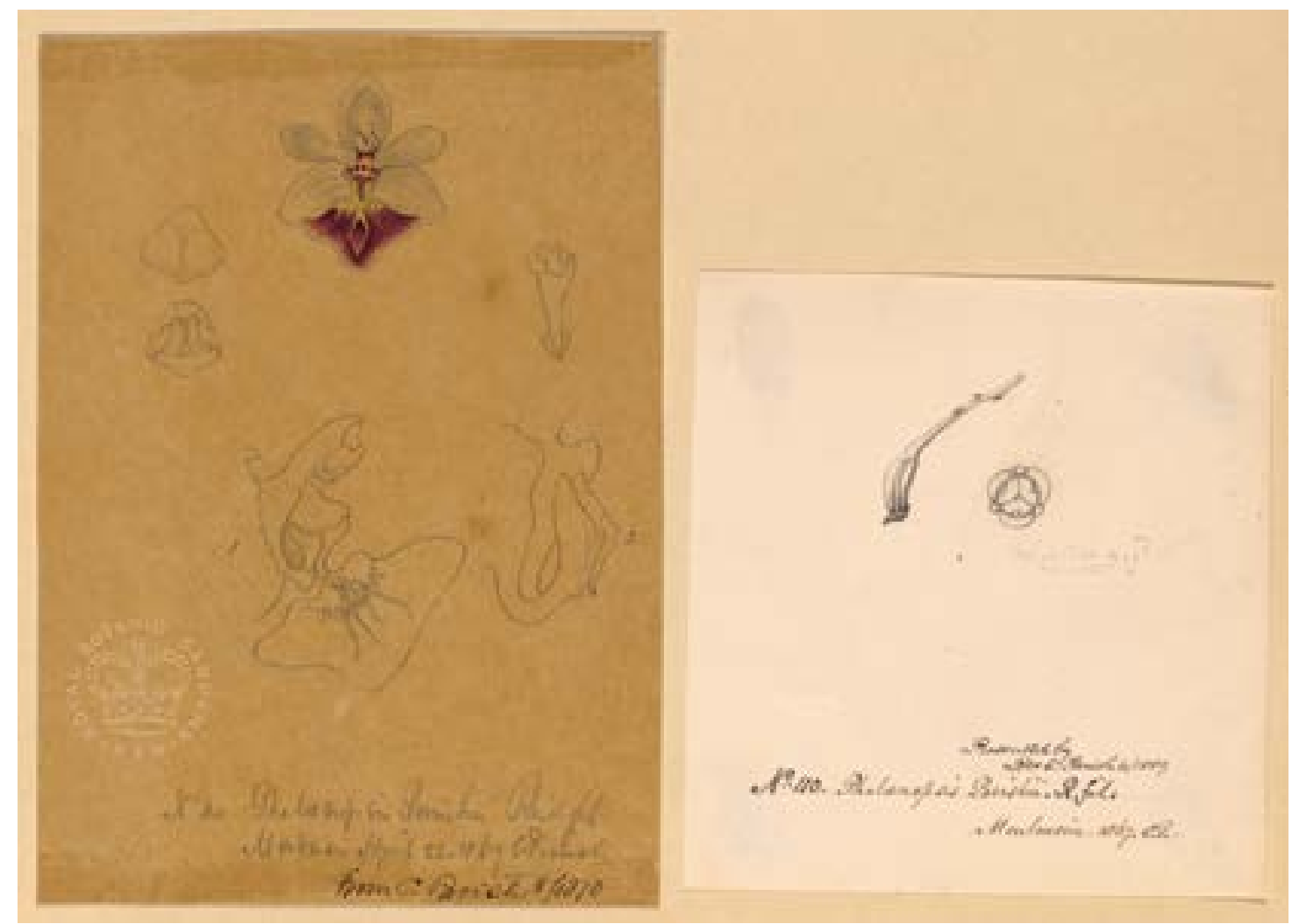

FIgure 10. Phalaenopsis parishii Rchb.f. in Bot. Zeitung (Berlin) 23: 146. 1865. Type: Burma, Tenasserim, Moulmein, Parish s.n. (holo. W-RCHB). Parish illustration vol. 2, p. 70, dated 20 April 1869. Reproduced with the kind permission of the Director and the Board of Trustees, Royal Botanic Gardens, Kew.

Sir William Jackson Hooker (1855-1865).

Kew Director's Correspondence (KDCAS5360-5363; KDCAS5365-5371; KDCAS5373-5380; KDCAS53825410; KDCAS5412-5413). Letters from CSP (Charles Samuel Pollock) Parish to Sir Joseph Dalton Hooker (1862-1882).

Mason, F. 1883. Burma, its people and productions; Notes on the fauna, flora and minerals of Tenasserim, Pegu and Burma. Vol. II, Botany, rewritten and enlarged by W. Theobald, Late Deputy-Superintendent Geological Survey of India. Published by Order of the Chief Commissioner of British Burma. Stephen Austin \& Sons, Hertford.

McNally, S.J. 1976. The Chaplains of the East India Company. List of all Chaplains appointed to the service of the East India Company 1601-1861 (transcript) with biographical details, compiled 1935-1976 by Sidney
James McNally, India Office clerk, 1922-1947. British Library, London, Oriental and India Office Collection.

Parish, C.S.P. 1856-1874. Drawings (coloured) of Orchidaceae (executed chiefly at Moulmein) in 2 volumes. Royal Botanic Gardens, Kew Catalogue No. 114242.

Parish, C.S.P. 1861. A Little Known Volcano, visited 19th October 1861 (a copy donated to the British Library by G.M. Parish, Broadstone, 1953. British Library, London, Oriental and India Office Collection, European Manuscripts, MSS. Eur. D674 (transcription by Dr L.A. Ryder (2012), Brisbane, Queensland, Australia).

Reichenbach, H.G. 1874. Enumeration of the orchids collected by the Rev. (E.C.) C.S.P. Parish in the neighbourhood of Moulmein, with descriptions of the new species in Transactions of the Linnean Society of London, 30: 133-155. London. 
